\title{
Induction of apoptosis in AK-5 tumor cells by a serum factor from tumor rejecting animals: cytochrome $c$ release independent of $\mathrm{Bcl}-2$ and caspases
}

\author{
R Anjum ${ }^{1}$, P Joshi ${ }^{1}$ and A Khar, ${ }^{*}$ \\ 1 Centre for Cellular \& Molecular Biology, Uppal Road, Hyderabad 500 007, India \\ * Corresponding author: A Khar, Centre for Cellular \& Molecular Biology, Uppal \\ Road, Hyderabad 500 007, India
}

Received 24.1.01; revised 24.4.01; accepted 24.5.01

Edited by L Fesus

\begin{abstract}
The ability to selectively induce apoptosis in tumor cells is the prime goal in cancer immunotherapy and aims at identifying potential molecular targets, regulating this process. Here we show that the sera from the animals which had spontaneously rejected the AK-5 tumor (a rat histiocytoma) had an effective and potent ability to counteract and kill tumor cells by inducing apoptosis, with a high degree of specificity. Apoptosis induced by the serum factor involved the activation of caspases and cytochrome crelease to the cytosol. A reduction in mitochondrial transmembrane potential $\left(\Delta \psi_{m}\right)$ occurred considerably later than cytochrome $c$ translocation. The antiapoptotic protein Bcl-2 and the pancaspase inhibitor ZVADfmk did not prevent cytochrome $c$ release, but completely blocked the reduction in $\Delta \psi_{\mathbf{m}}$, DNA fragmentation and apoptosis. Cyclosporin A (CsA), an inhibitor of the mitochondrial permeability transition (MPT) pore had no effect on cytochrome crelease and apoptosis mediated by serum factor in AK-5 cells, suggesting that apoptosis was independent of MPT. Taken together these results suggest that the serum factor in conjunction with the immune cells may be participating in the efficient rejection of the tumor in syngeneic hosts and $\Delta \psi_{\mathrm{m}}$ disruption but not cytochrome $\mathrm{c}$ release, is a critical and decisive event to trigger apoptotic cell death induced by the serum factor in AK-5 tumor cells. Cell Death and Differentiation (2001) 8, 1038-1046.
\end{abstract}

Keywords: apoptosis; cytochrome $c$; mitochondria; tumor regression

Abbreviations: Annexin V-FITC, fluorescein-conjugated annexin $\mathrm{V}$; CCCP, carbonylcyanide m-chlorophenylhydrazone; $\Delta \psi_{\mathrm{m}}$, mitochondrial transmembrane potential; MPT, mitochondrial permeability transition; $\mathrm{DiOC}_{6}(3), 3^{\prime}, 3^{\prime}$-dihexyloxacarbocyanine; DAPI, 4,6-diamidino-2-phenylindole; ANT, adenine nucleotide translocator; VDAC, voltage-dependent anion channel; CsA, cyclosporin A; AMC, 7-amino-4-methylcoumarin; PARP, poly(ADP-ribose) polymerase; PTPC, permeability transition pore complex; ETC, electron transport chain; AIF, apoptosis inducing factor; DEVD-CHO, Asp-Glu-Val-Asp aldehyde; YVAD-cmk, TyrVal-Ala-Asp chloromethylketone; zVAD-fmk, z-Val-Ala-Asp fluoromethylketone

\section{Introduction}

Apoptosis is a highly regulated, indispensable cell death process, intrinsic to all metazoan cells, for development and maintenance of homeostasis. Impairment of this process has been linked to the pathology of many forms of human diseases such as cancer, neurodegenerative disorders, ischemia and AIDS. ${ }^{1}$ Understanding the molecular mechanisms responsible for inducing or arresting this process and identifying targets for therapeutic intervention has been the ultimate goal of researchers.

Among the critical components of the cell death process are the caspases ${ }^{2,3}$ which form a proteolytic network within the cell. These are synthesized as dormant proenzymes, which get activated upon receiving an apoptotic stimulus. The caspases bring about the dismantling of the cellular structure, by the cleavage of key substrates resulting in cellular demise. ${ }^{4}$ Mitochondria have been shown to be the control point in the mainstream of apoptotic cascade in many cell types ${ }^{5-8}$ as well as in cell-free systems. ${ }^{9}$ Apoptosis in the majority of cells studied, proceeds with the translocation of apoptogenic factors such as cytochrome $c^{7,10-12}$ and apoptosis-inducing factor (AIF) ${ }^{13}$ from mitochondria to the cytosol. In the cytosol, cytochrome $c$ forms a complex with Apaf-1 and caspase-9, leading to the activation of caspase-3. ${ }^{14}$ The mechanism by which cytochrome $c$ is released into the cytosol is controversial but seems to be regulated in part by the Bcl-2 family of proteins. ${ }^{11,12}$ Earlier work has demonstrated that cytochrome $c$ efflux from mitochondria is either through Baxmediated channels ${ }^{15,16}$ or by the mechanism of mitochondrial permeability transition, ${ }^{17}$ (MPT) but none of the models have been proven definitively.

We have been working on the molecular mechanisms involved in the cell death of AK-5 tumor, a spontaneously regressing rat histiocytoma. ${ }^{18}$ The animals which regress the tumor are immune to further challenges, of this tumor. Here we show that the sera from the tumor rejecting animals have a potent apoptosis-inducing ability in vitro on AK-5 cells. Apoptosis in these cells proceeds with the release of cytochrome $c$ to the cytosol, followed by the disruption of mitochondrial transmembrane potential $\left(\Delta \psi_{\mathrm{m}}\right)$, concomitant with the nuclear fragmentation. Overexpression of $\mathrm{Bcl}-2$ in $\mathrm{AK}-5$ cells or treatment with a broad spectrum caspase inhibitor zVAD-fmk, prevented $\Delta \psi_{\mathrm{m}}$ loss and nuclear fragmentation, but not cytochrome $c$ release. The ability of the serum factor to 
induce apoptosis in tumor cells strongly supports the role of this factor in the spontaneous regression of the tumor.

\section{Results}

\section{Induction of apoptosis in AK-5 cells by the serum factor}

The AK-5 tumor, a rat histiocytoma is being maintained as ascites in an inbred colony of wistar rats. When injected intraperitoneally, AK-5 is highly malignant and kills all the animals, but subcutaneous transplantation results in solid tumors, which regress spontaneously in $80 \%$ of the animals. The animals which had rejected the tumor were immune to further challenges of the tumor by either route, and the serum from these animals had a potent apoptosis inducing ability on the BC-8/AK-5 cells in vitro. BC-8 cells incubated with decomplemented $10 \%$ (v/v) anti-AK-5 antiserum undergo all the classical features of apoptosis including chromatin condensation, membrane blebbing and DNA fragmentation. About $70 \%$ of the cells were rendered apoptotic by $12 \mathrm{~h}$ of treatment, as observed after propidium iodide staining (Figure 1). This factor present in the serum is highly specific to AK-5 cells, since it does not induce apoptosis in any other cell line tested (Table 1). The purified serum factor after protein G-sepharose chromatography gave a single peak which showed apoptotic activity. This fraction gave two bands on SDS-PAGE, corresponding to $55 \mathrm{kDa}$ heavy chain and $25 \mathrm{kDa}$ light chain of the immunoglobulin molecule (data not shown).

Apoptosis was also assessed by annexin $\mathrm{V}$ binding assay. ${ }^{19}$ The confocal images in Figure $2 \mathrm{~A}$ show no binding of annexin V-FITC to the normal cells and cells treated with

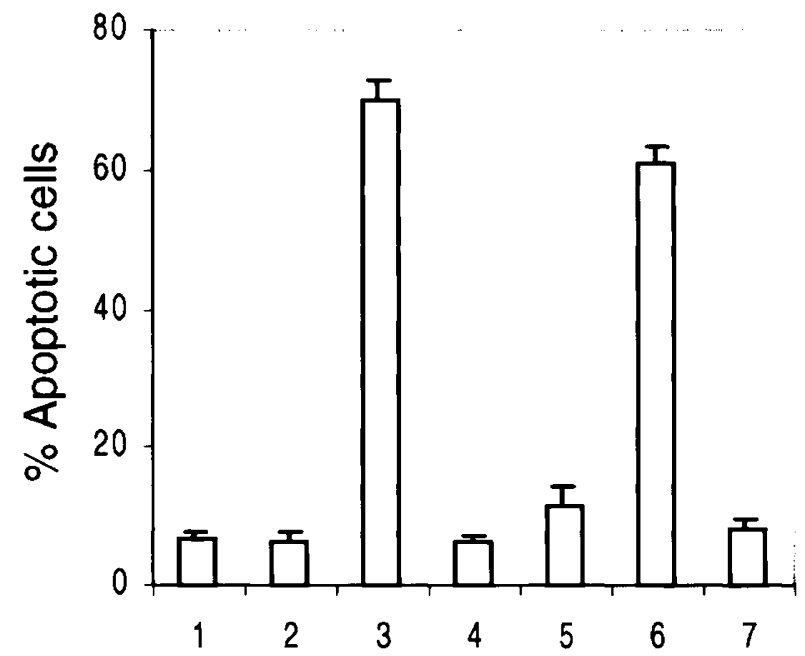

Figure 1 Quantitative determination of apoptosis in BC-8 cells, after treatment with the serum factor for $12 \mathrm{~h}$, and staining with propidium iodide. (1) control cells (2) cells treated with normal rat serum (3) cells treated with the serum factor. Cells were pretreated with (4) $100 \mu \mathrm{M}$ zVAD-fmk (5) $200 \mu \mathrm{M}$ DEVD-CHO (6) $100 \mu \mathrm{M}$ YVAD-cmk followed by the treatment with serum factor. (7) Bcl-2 overexpressing cells treated with the serum factor. Data represents mean \pm SEM of three independent experiments
Table 1 Specificity of serum factor induced apoptosis in different cell lines

\begin{tabular}{lc}
\hline Cell line & Apoptosis \\
\hline Jurkat & - \\
HeLa & - \\
HL-60 & - \\
Cos-1 & - \\
NIH3T3 & - \\
F111 & - \\
SW620 & - \\
MDAMB & - \\
BC-8 & + \\
\hline
\end{tabular}

$2 \times 10^{4}$ cells were treated with the serum factor for $24 \mathrm{~h}$. Apoptotic cells were scored based on the fragmented nuclear morphology after PI staining

normal rat serum, which show a normal nuclear morphology. In contrast, serum factor treated cells having either a condensed or a fragmented nuclei display the formation of a bright annexin ring on the cell surface. Flow cytometric analysis was done to assess plasma membrane integrity (PI staining) and annexin binding simultaneously. A bivariate analysis in Figure $2 \mathrm{~B}$ shows three distinct subpopulations of cells, double negative $\left(\mathrm{Av}^{-} / \mathrm{PI}^{-}\right)$, single positive cells $\left(\mathrm{Av}^{+} / \mathrm{Pl}^{-}\right)$and double positive cells $\left(\mathrm{Av}^{+} / \mathrm{Pl}^{+}\right)$. The binding of annexin $\mathrm{V}$ was seen from $6 \mathrm{~h}$ onwards and was maximum around $10 \mathrm{~h}$, the plasma membrane integrity was retained for a longer time. There was an increase in the number of $\mathrm{Av}^{+} / \mathrm{PI}^{-}$cells (apoptotic) with increase in time, with the concomitant decrease in the number of $\mathrm{Av}^{-}$/ $\mathrm{PI}^{-}$, live cells.

\section{Serum factor-induced apoptosis is caspase- dependent}

In order to ascertain the involvement of caspases, in serum factor-induced apoptosis, inhibition studies were carried out using peptide inhibitors. The broad spectrum, cell permeable, inhibitor of caspases, zVAD-fmk at $100 \mu \mathrm{M}$ concentration, completely blocked cell death, in these cells, as assessed by PI staining (Figure 1). zVAD treatment inhibited the nuclear pyknosis, and fragmentation, indicating effective inhibition of cellular caspases. Similar results were obtained using caspase-3 specific inhibitor, Ac-DEVD-CHO. However, caspase-1 specific inhibitor AcYVAD-cmk failed to prevent apoptosis (Figure 1).

To further confirm the potential involvement of caspase3 , cytosolic extracts were tested for their ability to cleave the fluorogenic substrate of caspase-3, DEVD-AMC. Caspase-3 activity increased significantly after treatment with serum factor, reached peak value at $12 \mathrm{~h}$ (Figure $3 \mathrm{~A}$ ). In the presence of DEVD-CHO, the DEVD-dependent protease activity was reduced to the control level. YVAD$\mathrm{AMC}$ on the other hand, showed no detectable activity. Activation of caspase-3 was also confirmed by the timedependent degradation of poly(ADP-ribose) polymerase (PARP), a well known endogenous substrate of caspase3. ${ }^{20}$ Incubation of BC-8 cells with the serum factor resulted in a marked increase in the $85 \mathrm{kDa}$ cleavage product of PARP, at $6 \mathrm{~h}$, which continued to increase up to $10 \mathrm{~h}$ (Figure 3B). 
A
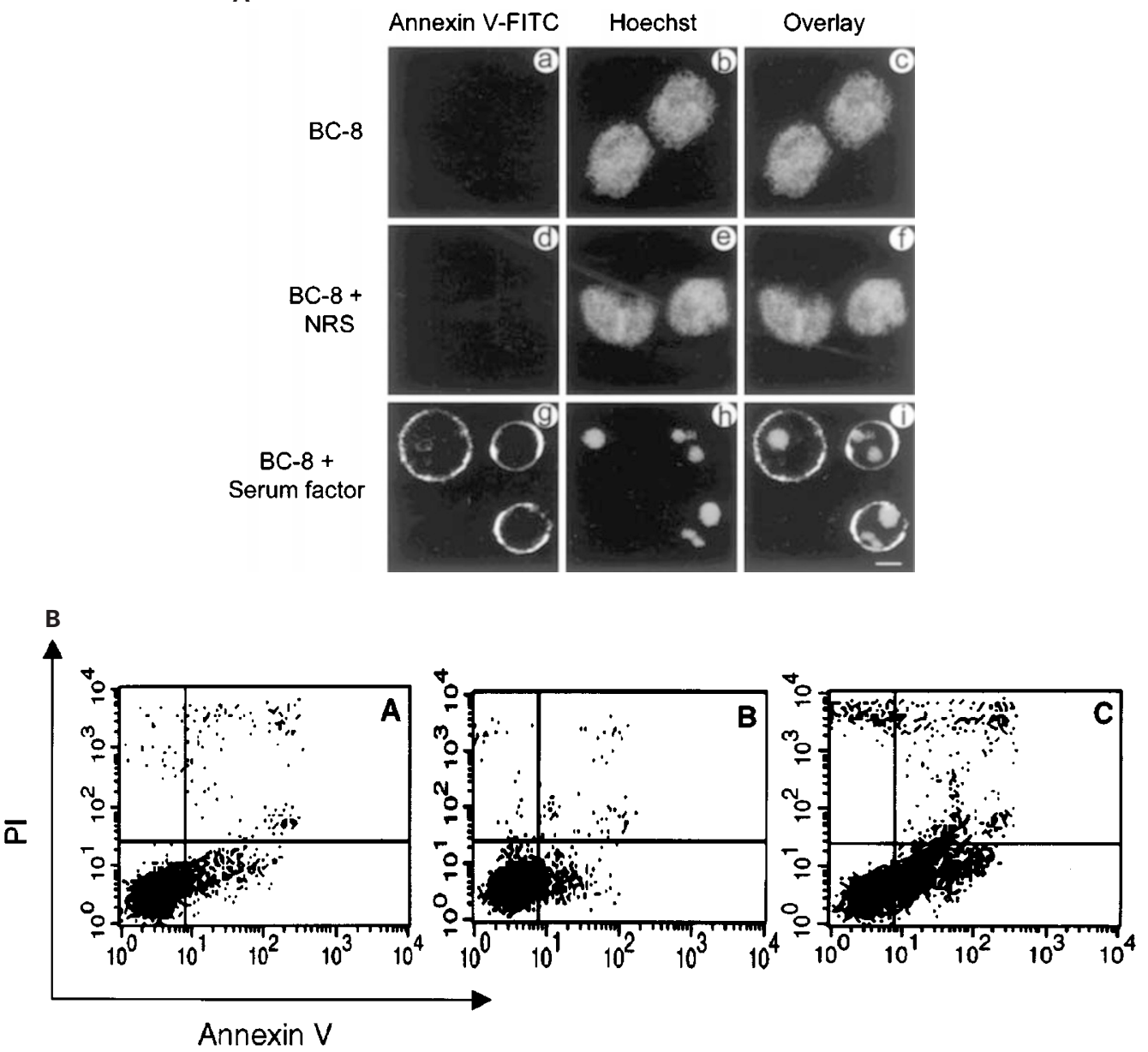

Figure 2 Phosphatidylserine externalization in BC-8 cells undergoing apoptosis (A) Control BC-8 cells, cells treated with normal rat serum and the serum factor for $8 \mathrm{~h}$ were analyzed by confocal microscopy after staining with Annexin V-FITC (a, d, g). Nuclear morphology was revealed by Hoechst staining (b, e, h). $\mathrm{c}, \mathrm{f}, \mathrm{i}$ represent the overlay of two images. Scale bar represents $10 \mu \mathrm{m}$. (B) flow cytometric analysis of annexin $\mathrm{V}$ binding and plasma membrane integrity (propidium iodine staining) in BC-8 cells undergoing apoptosis. (A) untreated BC-8 cells. (B) BC-8 cells treated with normal rat serum and (C) after treatment with serum factor for $10 \mathrm{~h}$

\section{Apoptosis in BC-8 cells is accompanied by cytochrome $c$ release}

Confocal immunofluorescence microscopy demonstrates that in untreated BC-8 cells, cytochrome $c$ is mitochondrial and showed punctate staining pattern which colocalizes to the mitochondria-specific dye CMXRos; and the nucleus shows a normal morphology (Figure 4A). The diffused staining pattern of cytochrome $c$, starts appearing at $2 \mathrm{~h}$ of treatment and it continues for $6-8 \mathrm{~h}$, with the nucleus showing a condensed appearance. By about $8 \mathrm{~h}$, most of the cytochrome $c$ is cytosolic and the nucleus shows a fragmented morphology as assessed by DAPI staining.

Immunoblotting was also done to detect levels of cytochrome $c$ in both soluble cytosolic and the mitochondria-enriched, heavy membrane fractions (the pellet), obtained from BC-8 cells treated with the serum factor. The results indicate that the control cells contained almost no detectable cytochrome $c$ in the cytosol, in contrast there was a significant efflux of this protein in the cytosol of treated cells which progressively increased with time, reaching a peak at $10 \mathrm{~h}$ with a concomitant decrease in immunoreactivity in the pellet fraction (Figure 4B). The absence of cytochrome $c$ oxidase (subunit IV) in the supernatant fraction rules out the possibility of mitochondrial contamination in cytosol (Figure 4B).

\section{Cytochrome $c$ translocation to cytosol precedes the breakdown of mitochondrial membrane potential}

To investigate whether a reduction in $\Delta \psi_{\mathrm{m}}$, could explain the mitochondrial cytochrome $c$ efflux during apoptosis in $\mathrm{BC}-8$ cells, we have monitored the mitochondrial membrane potential, using the mitochondrial potential-sensitive fluorescent dye, $\mathrm{DiOC}_{6}(3) .{ }^{21}$ After exposure of $\mathrm{BC}-8$ cells, to the serum factor, there was no change in the retention of the dye for about $6 \mathrm{~h}$ and the decline was seen from $8 \mathrm{~h}$ onwards (Figure 5D), concomitant with the nuclear DNA fragmentation, the time at which most of the cytochrome $c$ is already 
A

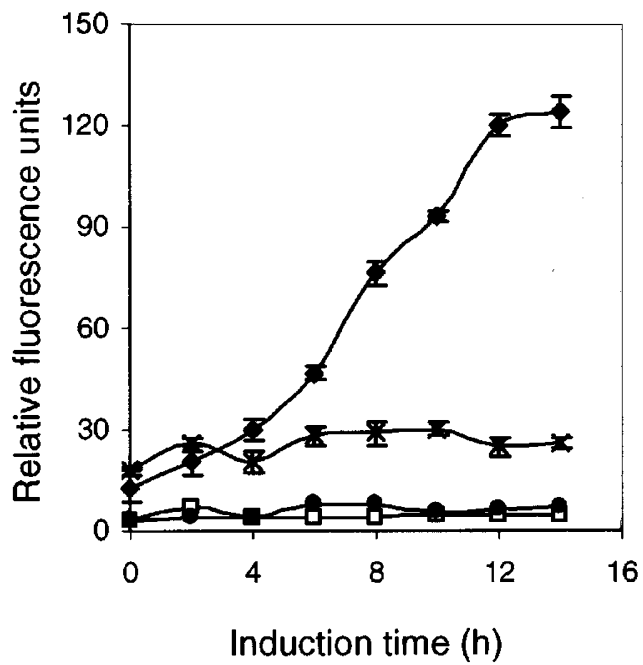

B

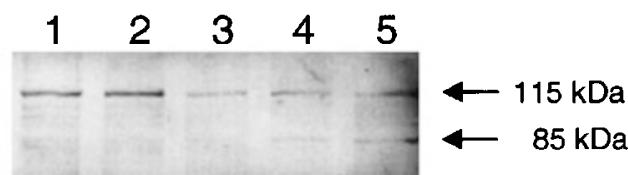

Figure 3 Apoptosis in BC-8 cells proceeds with the activation of caspase-3. (A) Time-dependent activation of caspase $3(\checkmark)$ upon treatment with the serum factor, whereas there was no increase in caspase-1 activity ( $\square$ ). Pretreatment of the cells with zVAD-fmk, followed by the treatment with serum factor, completely inhibited caspase-3 activity $(0)$. Cells treated with normal rat serum did not show activation of caspase-3 $(x)$. (B) Immunoblot showing the cleavage of PARP in cells treated with the serum factor for $2 \mathrm{~h}$ (lane 2 ), $4 \mathrm{~h}$ (lane 3), $6 \mathrm{~h}$ (lane 4 ) and $8 \mathrm{H}$ (lane 5) respectively. Lane 1 represents untreated BC-8 cells

released. Similar results were obtained using the mitochondrial potential-sensitive, cationic, lipophilic dye, CMXRos (data not shown).

To emphasize the fact that the uptake of $\mathrm{DiOC}_{6}(3)$ by mitochondria really reflects $\Delta \psi_{\mathrm{m}}$, cells were treated with carbonyl cyanide m-chlorophenylhydrazone (CCCP, $50 \mu \mathrm{M})$, a protonophore that dissipates $\Delta \psi_{\mathrm{m}}$, and the entire cell population, shifted to weaker fluorescence (Figure 5B). These data emphasize that the dissipation of mitochondrial potential is not the cause for the release of cytochrome $c$ in BC-8 cells.

\section{Cytochrome $c$ translocation is independent of caspases and $\mathrm{Bcl}-2$ overexpression}

In the earlier experiments, we have seen that blocking caspase activation prevents apoptosis, and prolongs cell survival in BC-8 cells. Overexpression of the proto-oncogene $\mathrm{Bcl}-2$ in these cells has been shown to prevent apoptosis (Figure 1). We next tested whether cell viability is a reflection of the prevention of cytochrome $c$ efflux by either caspase inhibitors or the overexpression of $\mathrm{Bcl}-2$.
Bcl-2 overexpressing cells and BC-8 cells pretreated with $100 \mu \mathrm{M} z V A D$-fmk for 30 min were induced with the serum factor for $6 \mathrm{~h}$. Immunoblot analysis of both the soluble cytosolic and heavy membrane fraction showed a time bound release of cytochrome $c$ from mitochondria to the cytosol (Figure 6).

\section{Release of cytochrome $c$ does not dissipate the mitochondrial membrane potential}

In contrast to earlier studies, our studies suggest that cytochrome $c$ release precedes $\Delta \psi_{\mathrm{m}}$, and is independent of $\mathrm{Bcl}-2$ and caspases. Though $\mathrm{Bcl}-2$ overexpressing and zVAD treated cells, upon induction with the serum factor, exhibited translocation of cytochrome $c$ to the cytosol, the disruption of mitochondrial potential was completely prevented, as shown by $\mathrm{DiOC}_{6}$ staining (Figure $5 \mathrm{E}, \mathrm{F}$ ). $\Delta \psi_{\mathrm{m}}$ was maintained for a long time concomitant with the preservation of nuclear morphology. These data suggest that loss in mitochondrial potential is not a consequence of cytochrome $c$ translocation and the release of cytochrome $c$ has no effect on the survival of BC-8 cells. The data also show that mitochondrial depolarization is caspase-dependent and inhibited by Bcl-2 overexpression.

\section{Inhibition of MPT does not prevent cytochrome $c$ release and apoptosis}

With a view to find out whether the release of cytochrome $c$ in BC-8 cells is by the mechanism of MPT, we have used cyclosporin $A(C s A)$, which specifically inhibits cyclophilin $D,{ }^{22}$ a matrix localized protein of the mitochondrial permeability pore complex (MPPC). Pretreatment of cells with 5 or $10 \mu \mathrm{M}$ CsA for $1 \mathrm{~h}$, followed by the treatment with serum factor did not prevent apoptosis in BC-8 cells. There was a significant efflux of cytochrome $c$ into the cytosol, as seen by Western analysis (Figure 7). CsA was non-toxic to BC-8 cells at the concentration used in these experiments. These results suggest that the release of cytochrome $c$ in these cells does not involve MPT.

\section{Discussion}

Apoptosis maintains a balance between cell proliferation and cell death, thus regulating cellular homeostasis. Inappropriate or excessive apoptosis has been linked to the pathophysiology of many disease conditions. The uncontrolled growth of the tumor in cancerous conditions is attributed to the circumvention of apoptotic signaling pathways in tumor cells, that would normally lead to their elimination. ${ }^{23}$ Tumor cells have also developed the capability of inducing apoptosis and destroying effector cells by the mechanism of immune evasion. ${ }^{24}$ Thus there are intrinsic factors which would give a selective advantage for tumor cells to proliferate unconditionally. The identification of specific genes regulating the normal apoptotic signaling would facilitate the selective killing of tumor cells.

Work in our laboratory has been focused on deciphering the molecular mechanisms responsible for the spontaneous regression of AK-5 tumor. Intraperitoneal injection of AK-5 


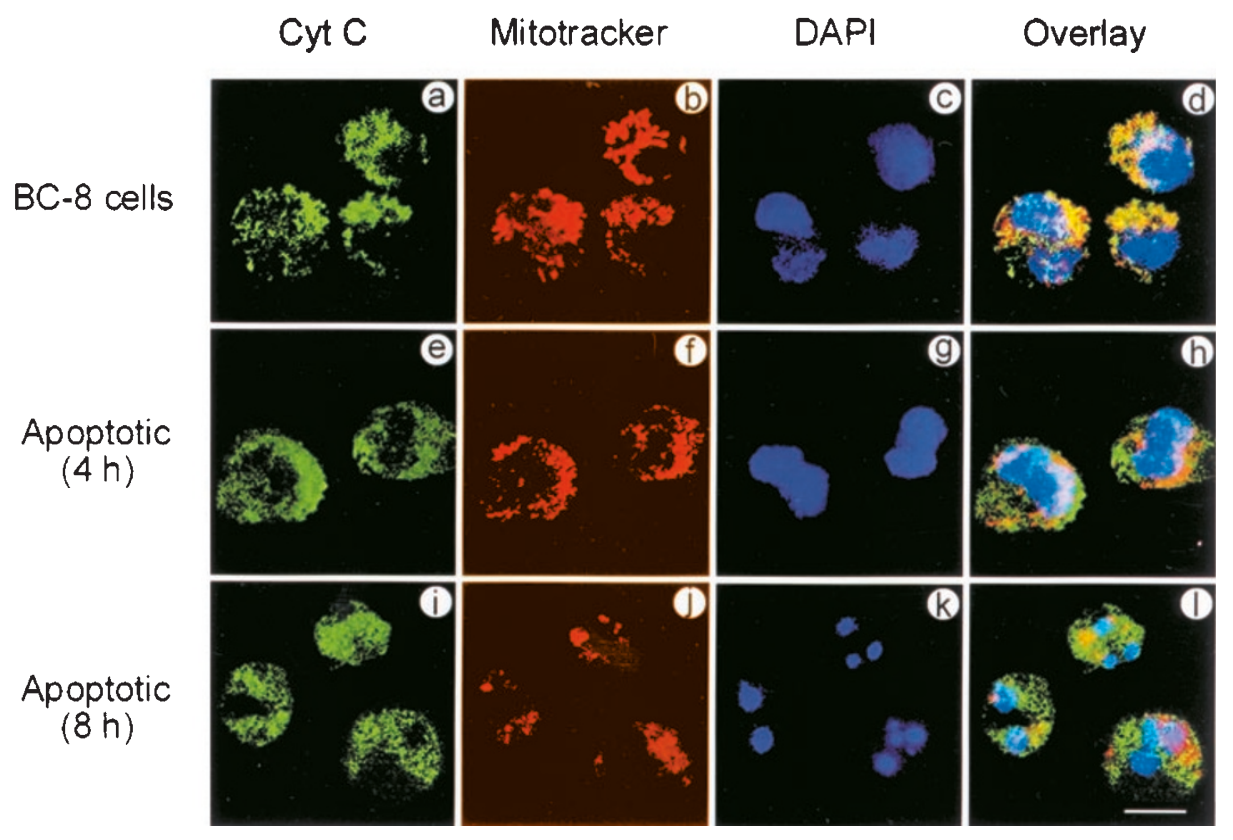

B

Time (h)

\begin{tabular}{|l|l|l|l|l|l|l|l|}
\hline \multicolumn{4}{|c|}{ Pellet } & \multicolumn{4}{c|}{ Supernatant } \\
\hline 0 & 4 & 8 & 10 & 0 & 4 & 8 & 10 \\
\hline
\end{tabular}

Cyt C

COXIV

Figure 4 Apoptosis in BC-8 cells is accompanied by cytochrome $c$ release. (A) Subcellular localization of cytochrome $c$ was visualized in untreated cells and cells treated with the serum factor for 4 and $8 \mathrm{~h}$ respectively, after immunofluorescence and confocal microscopy. Panels a, e and i show cytochrome $c$ pattern. Mitochondria were visualized by staining with Mitotracker red (CMXRos) (b, f, j). DAPI staining of the corresponding nuclei is also shown (c, g, k). $d, h, I$, represent the overlay of all three images. Images were obtained by confocal analysis of $0.2 \mu \mathrm{m}$ optical section. Scale bar represents $10 \mu \mathrm{m}$. (B) Western blot analysis showing time bound release of cytochrome $c$ in the cytosol. COX IV staining serves as a loading control and also rules out the possibility of mitochondrial contamination in the cytosol

cells in Wistar rats, leads to the development of ascites, and the animal dies due to high tumor load by day 6-10. However, if injected subcutaneously, the tumor grows for about 2 weeks, and starts regressing thereafter. The tumor site gets healed completely in about 35 days. We have previously shown that the killing of AK-5 cells occurs by both necrosis (perforin mediated) and apoptosis. ${ }^{25} \mathrm{We}$ have also identified NK cell as the effector which mediates apoptosis of AK-5 cells in vivo. ${ }^{26}$ In the present study we show the induction and molecular mechanisms of apoptosis in vitro in $\mathrm{AK}-5$ cells, by a unique serum factor derived from tumor regressing animals. Characterization of the biochemical nature of this factor, showed it to be an immunoglobulin molecule. Work done earlier had ruled out the possible involvement of Fas-Fas $L$ or the classical tumor necrosis factor $\alpha(\mathrm{TNF} \alpha)$-TNF receptor interaction in apoptosis induced by the serum factor.

Apoptosis induced by the serum factor has all the classical characteristics of apoptosis occurring with exquisite synchrony. The formation of oligonucleosomal ladder, a hall mark of apoptosis ${ }^{27}$ was seen at $12 \mathrm{~h}$ postinduction (data not shown). Externalization of PS from the inner to the outer leaflet of plasma membrane is a mechanism wherein the apoptotic cells display a number of 'eat me' signals to be recognized by the macrophages. ${ }^{28}$ As opposed to the earlier findings which showed PS flipping as an early critical event in the induction of apoptosis, ${ }^{19,28}$ regardless of the apoptotic stimulus, we show that PS flipping occurs late in the apoptotic process in $\mathrm{BC}-8$ cells which is paralleled by nuclear fragmentation. 


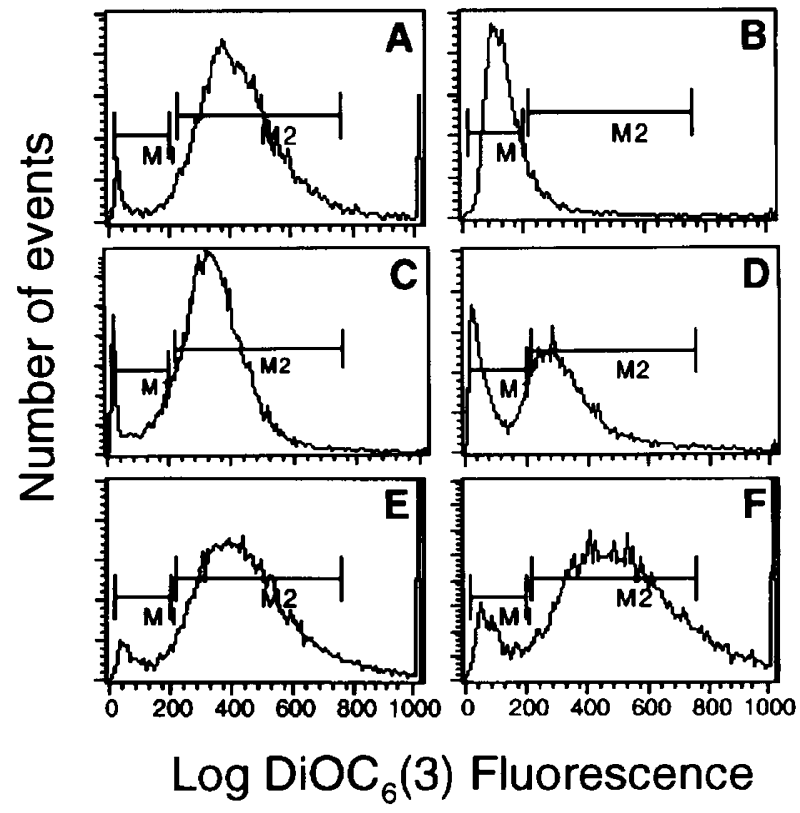

Figure 5 Measurement of $\Delta \psi_{\mathrm{m}}$ by DiOC6(3) staining and flow cytometry. (A) represents untreated BC-8 cells. (C) and (D) correspond to cells treated with normal rat serum and the serum factor for $10 \mathrm{~h}$. Bcl-2 overexpressing cells $(E)$ as well as ZVAD-fmk $(100 \mu \mathrm{M})$ pretreated cells $(\mathbf{F})$ did not show a loss in $\Delta \psi_{\mathrm{m}}$ As a positive control for reduction of $\Delta \psi_{\mathrm{m}}$, cells were treated with CCCP $(50 \mu \mathrm{M})$, a mitochondrial uncoupling agent (B)

A

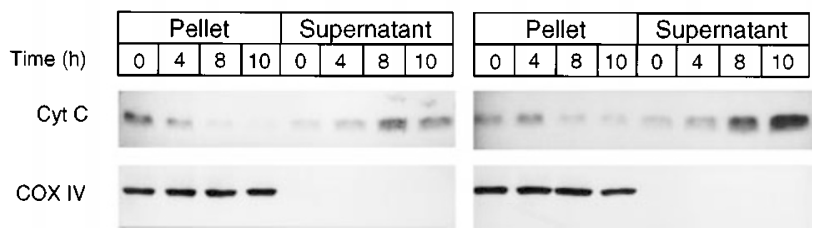

Figure 6 Cytochrome $c$ release in BC-8 cells is independent of Bcl-2 overexpression and caspase activation. Western analysis of mitochondrial and cytosolic fractions of $\mathrm{Bcl}-2$ overexpressing (A) and zVAD-fmk treated cells (B), after induction with the serum factor

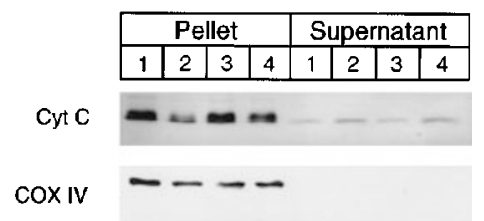

Figure 7 MPT inhibitor, CsA does not prevent release of cytochrome $c$. Western analysis showing that CsA had no effect on the cytochrome $c$ release. Lane 1, untreated BC-8 cells; lane 2, BC-8 cells treated with the serum factor for $8 \mathrm{~h}$; lane 3 and 4 correspond to the cells pretreated for $1 \mathrm{~h}$ with CsA and induced with the serum factor for 4 and $8 \mathrm{~h}$ respectively

Release of cytochrome $c$ from the mitochondria to cytosol is invariably associated with apoptosis in most of the systems studied ${ }^{6,7,11,12}$ with few exceptions. ${ }^{29,30}$ Cytochrome $c$ translocation was shown to be regulated by the $\mathrm{Bcl}-2$ family of proteins with the anti-apoptotic proteins
$\mathrm{Bcl}-2$ and $\mathrm{Bcl}-\mathrm{X}_{\mathrm{L}}$ preventing its release and hence apoptosis ${ }^{11,12,31}$ and the ectopic expression of the death promoter Bax triggers cytochrome $c$ release from mitochondria in the absence of any death stimulus. ${ }^{8,32}$ Cytochrome $c$ was released quite early in BC-8 cells induced with the serum factor, concomitant with caspase activation. By around $10 \mathrm{~h}$, most of the cytochrome $c$ was cytosolic, though some mitochondria still retained the protein. Overexpression of $\mathrm{Bcl}-2$ protein though prevented apoptosis, yet did not prevent release of cytochrome $c$ in BC-8 cells. Treatment of the cells with the pan-caspase inhibitor zVAD-fmk also had a similar effect. This is consistent with recent studies which demonstrate that cytochrome $c$ release is an upstream process in the cascade of cell death. ${ }^{7}$ Depletion of cytochrome $c$, a protein obligatory for oxidative phosphorylation and cell survival is intriguing. Studies by Martinou et al. ${ }^{33}$ demonstrated that translocation of cytochrome $c$ is a reversible event with the depleted cells acquiring cytochrome $c$ by de-novo protein synthesis.

The release of cytochrome $c$ did not result in loss of mitochondrial membrane potential as proposed earlier in some studies. ${ }^{7}$ But the loss of $\Delta \psi_{\mathrm{m}}$ always paralleled nuclear fragmentation. The ability of zVAD and Bcl-2 overexpression to prevent $\Delta \psi_{\mathrm{m}}$ suggests that this process is caspase-dependent, and regulated by $\mathrm{Bcl}-2$, which acts downstream of cytochrome $c$ release and is also the critical point which determines cell death. In zVAD and Bcl-2 overexpressing cells, where almost all the cytochrome $c$ is released, the cells still maintain a high membrane potential. This suggests that $\Delta \psi_{\mathrm{m}}$ loss is not a consequence of cytochrome $c$ release or the disruption of electron transport chain (ETC). It was also shown earlier that $\rho_{0}$ cells which lack a function ETC due to deletion of their mitochondrial DNA, exhibit a normal $\Delta \psi_{\mathrm{m}}$ and are able to undergo PT and apoptosis. $^{34}$

Recent studies demonstrated that the release of cytochrome $c$ from mitochondria is by the phenomenon of MPT, wherein there is opening of the so called 'permeability transition pore' (PTP), a high conductance, unselective channel formed by the apposition of transmembrane proteins from both the membranes of mitochondria. ${ }^{35}$ These include adenine nucleotide translocator (ANT), voltage-dependent anion channel (VDAC), matrix localized cyclophilin D, and other small proteins. MPT can be blocked by using specific inhibitors, which bind these proteins, and prevent apoptosis in different systems. CsA treatment did not inhibit apoptosis induced by the serum factor, suggesting that MPT does not play a role in cytochrome $c$ release. CsA binds to cyclophilin D, which in turn interacts with ANT and VDAC, together forming the permeability transition pore complex (PTPC). ${ }^{36}$ This suggests that either other components of the PTPC may be involved and alternate permeabilization mechanisms exist, or MPT is not the mechanism leading to cytochrome $c$ release. There are also studies which suggest that the inhibitory effects of CsA on PT are transitory. ${ }^{36}$ Therefore it is not clear whether the inability of CsA to inhibit MPT is a mere reflection of its inability to function as an inhibitor or whether PTPC involves a complex interaction. 
The efficient and selective killing of malignant cancerous cells can be achieved by switching on of the death promoting genes or the switching off of the survival genes. In fact, it was found that most drugs used in anticancer therapy kill target cells by the induction of apoptosis. ${ }^{37}$ Spontaneous regression of the tumors is the natural event by which the immune system counteracts and kills tumor cells by the interplay of a complex interaction between the host and the target. The AK-5 tumor is an excellent model to study the mechanisms of apoptosis in vivo The switching on, of an apoptotic program in AK-5 tumor cells in vitro by a unique serum-derived factor, reflects the possible apoptotic mechanism in vivo, leading to the spontaneous tumor rejection.

\section{Materials and Methods}

\section{Animals, tumor and cell culture}

AK-5 tumor was maintained as ascites in an inbred colony of Wistar rats by injecting $5 \times 10^{6}$ tumor cells i.p. ${ }^{18}$ Animals which were injected with tumor cells $\left(5 \times 10^{6}\right)$ subcutaneously and had rejected the tumor were used as the source for the serum factor. We have also used a single cell clone of AK-5 adapted to grow in vitro, called BC-8 in all the studies, to avoid ambiguity in results due to tumor heterogeneity. ${ }^{38}$ BC-8 cells were grown in DMEM supplemented with $10 \%(\mathrm{v} / \mathrm{v})$ heat inactivated fetal calf serum in an atmosphere of $95 \%$ air and $5 \% \mathrm{CO}_{2}$. All other cell lines used in this study were grown in DMEM-FCS. Cell viability was assessed by trypan blue dye exclusion assay.

\section{Induction of apoptosis and fluorescence microscopy}

After treatment with the serum factor for appropriate time, cells were washed twice with PBS, and fixed in $80 \%$ methanol. They were then stained with $1 \mu \mathrm{g} \mathrm{ml}^{-1}$ propidium iodide reagent (Calbiochem), and observed under a fluorescence microscope (Nikon Optiphot). Apoptotic cells were identified based on the fragmented nuclear morphology.

\section{Purification of the serum factor}

Pooled, decomplemented sera from tumor rejecting animals were subjected to $45 \%$ ammonium sulphate precipitation. The dissolved precipitate was fractionated on DEAE-sephadex ion exchange column. The eluate fraction, active for apoptosis was purified further on protein G-sepharose affinity column. The active eluate fractions were pooled, concentrated by ultrafiltration (Amicon) and dialyzed against PBS. The purified preparation was analyzed by SDS-PAGE for its homogeneity after silver staining.

\section{Detection and quantitation of apoptosis using the Annexin V assay}

BC-8 cells $\left(2 \times 10^{6}\right)$ induced to undergo apoptosis were stained with annexin V-FITC (Boehringer Mannheim) and Hoechst 33342 $\left(1 \mu \mathrm{g} \mathrm{ml}^{-1}\right)$ in binding buffer (10 mM HEPES, pH 7.4, $140 \mathrm{mM} \mathrm{NaCl}$, $5 \mathrm{mM} \mathrm{KCl}_{1} 1 \mathrm{mM} \mathrm{MgCl}_{2}, 2.5 \mathrm{mM} \mathrm{CaCl}_{2}, \mathrm{pH} 7.4$ ) at $4^{\circ} \mathrm{C}$ for $15 \mathrm{~min}$. The binding of annexin V-FITC to phosphatidylserine exposed on the cell surface was analyzed by laser scanning confocal microscopy.
Loss of plasma membrane integrity and quantitation of apoptosis was done by costaining the cells with Annexin V-FITC and propidium iodide $^{39}\left(1 \mu \mathrm{g} \mathrm{ml}^{-1}\right)$ (Boehringer, Mannheim) according to manufacturer's instructions and analyzed by flow cytometry.

\section{Fluorescence assay for caspase activation}

The activation of caspases was determined as described earlier ${ }^{40}$ with a few modifications. Briefly, $3 \times 10^{6}$ cells were lysed in lysis buffer $(1 \%$ Triton X-100, $0.32 \mathrm{M}$ sucrose, $5 \mathrm{mM}$ EDTA, $10 \mathrm{mM}$ Tris- $\mathrm{HCl}$, $\mathrm{pH} 8$, $2 \mathrm{mM}$ DTT, $1 \mathrm{mM}$ PMSF, $1 \mu \mathrm{g} \mathrm{ml}^{-1}$ aprotinin, $1 \mu \mathrm{g} \mathrm{ml}^{-1}$ leupeptin) for $15 \mathrm{~min}$ at $4^{\circ} \mathrm{C}$ followed by centrifugation $(20000 \times g)$ for $15 \mathrm{~min}$. Caspase- 1 and caspase- 3 activities were detected in the supernatants by measuring the proteolytic cleavage of the fluorogenic substrates YVAD-AMC and DEVD-AMC ${ }^{41}$ respectively. The reaction mixtures consisting of $50 \mu \mathrm{g}$ of extracts and $100 \mu \mathrm{M}$ substrate in $50 \mu \mathrm{l}$ assay buffer (100 mM HEPES, 10\% sucrose, $0.1 \%$ CHAPS, 2 mM DTT, $1 \mathrm{mM}$ PMSF, $1 \mu \mathrm{g} \mathrm{ml}^{-1}$ aprotinin, $1 \mu \mathrm{g} \mathrm{ml}^{-1}$ leupeptin) were incubated at $30^{\circ} \mathrm{C}$ for $1 \mathrm{~h}$ and the fluorescence was measured in a spectrofluorimeter at an excitation wavelength of $380 \mathrm{~nm}$ and an emission wavelength of $460 \mathrm{~nm}$.

\section{Poly(ADP-ribose) polymerase cleavage assay}

BC- 8 cells treated with serum factor for different time points were lysed in $1 \mathrm{X}$ sample buffer $(50 \mathrm{mM}$ Tris- $\mathrm{HCl}, \mathrm{pH} 6.8,100 \mathrm{mM}$ dithiothrietol, $2 \%$ SDS, $10 \%$ glycerol, $0.1 \%$ bromophenol blue). Equal amounts of proteins were fractionated on a $8 \%$ polyacrylamide gel and electroblotted onto a nitrocellulose membrane. Immunoblotting was done using a mouse anti-PARP monoclonal antibody (Pharmingen) and anti-mouse IgG-AP and the specific bands were revealed using NBT and BCIP.

\section{Subcellular fractionation and Western blotting}

Extraction of mitochondria and cytosol was done according to the previously published procedure. ${ }^{29}$ Briefly, BC-8 cells $\left(5 \times 10^{6}\right)$, at the end of treatment were washed with ice-cold PBS, and resuspended in $500 \mu \mathrm{l}$ of buffer A (20 mM HEPES- $\mathrm{KOH}, \mathrm{pH} 7.5$, $10 \mathrm{mM} \mathrm{KCl}, 1.5 \mathrm{mM} \mathrm{MgCl} 2,1 \mathrm{mM}$ sodium EDTA, $1 \mathrm{mM}$ sodium EGTA, $1 \mathrm{mM}$ dithiothreitol) containing $250 \mathrm{mM}$ sucrose and protease inhibitors ( $1 \mathrm{mM}$ PMSF, $1 \mu \mathrm{g} \mathrm{ml}^{-1}$ each of leupeptin, aprotinin, pepstain and chymostatin). The cells were homogenized by giving 40 strokes in a glass homogeniser using a B type pestle. Unlysed cells and nuclei were removed by centrifuging the supernatants at $1000 \times \mathrm{g}$ at $4^{\circ} \mathrm{C}$ for $10 \mathrm{~min}$. The resulting supernatant was subjected to $10000 \times g$ centrifugation at $4^{\circ} \mathrm{C}$ for $20 \mathrm{~min}$. The pellet fraction (mitochondria) was washed with buffer A, and solubilized in TNC buffer (10 mM Tris-acetate, $\mathrm{pH} 8.0,0.5 \%$ $\mathrm{NP}-40,5 \mathrm{mM} \mathrm{CaCl} 2)$. The supernatant was recentrifuged at $100000 \times g\left(4^{\circ} \mathrm{C}, 1 \mathrm{~h}\right)$ to generate cytosol. Protein concentration was determined by Lowry's method. Twenty-five micrograms of pellet fractions and $50 \mu \mathrm{g}$ of cytosolic fractions were subjected to $12.5 \%$ SDS-PAGE. Separated proteins were transferred to a nitrocellulose membrane and probed with 1:1000 dilution of monoclonal antibody to cytochrome $c$ (Pharmingen, San Diego, CA, USA). Mitochondrial contamination of cytosolic extracts was determined by probing the blot with mouse anti-cytochrome $c$ oxidase subunit IV (Molecular Probes Inc., Eugene, OR, USA). The blots were treated with an appropriate secondary antibody conjugated to alkaline phosphatase (Boehringer, Mannheim, Germany) and developed using NBT and BCIP. 


\section{Transfection of $\mathrm{BC}-8$ cells with $\mathrm{Bcl}-2$ gene}

BC- 8 cells $\left(2 \times 10^{6}\right)$ were transfected with the linearized pMEP4 vector, with and without full length murine $\mathrm{Bcl}-2$ gene by the electroporation method described earlier. ${ }^{42}$ The transfected clones were selected with hygromycin B $\left(400 \mu \mathrm{g} \mathrm{ml}^{-1}\right)$ for 14 days. Single cell clones were obtained by limiting dilution procedure. Clones were screened by Southern and Northern hybridizations and the positive clones were expanded and used in these studies.

\section{Measurement of mitochondrial transmembrane potential}

Mitochondrial energization was determined as the retention of the dye $3^{\prime}, 3^{\prime}$-dihexyloxacarbocyanine, $\mathrm{DiOC}_{6}(3)$ (Molecular Probes Inc., Eugene, OR, USA). BC-8 cells $\left(1 \times 10^{6}\right)$ at different time points of apoptotic induction were washed twice with PBS, and treated with $50 \mathrm{nM} \mathrm{DiOC}{ }_{6}(3)$ at $37^{\circ} \mathrm{C}$ for $30 \mathrm{~min}$. The cells were washed and the quantitation of cells retaining $\mathrm{DiOC}_{6}(3)$ was done in a FACStar PLUS Cytofluorometer (Becton-Dickinson, San Jose, CA, USA), using the Cell-Quest software. Carbonylcyanide m-chlorophenylhydrozone (CCCP; $50 \mu \mathrm{M})$ was used as a positive control for maximum $\Delta \psi_{\mathrm{m}}$ disruption.

\section{Immunocytochemistry}

Cells were treated with $20 \mathrm{ng} \mathrm{ml}^{-1}$ of mitochondria specific dye (mitotracker red CMXRos, Molecular Probes Inc., Eugene, OR, USA $)^{43}$ for $30 \mathrm{~min}$. They were washed and fixed in $3.5 \%$ paraformaldehyde in PBS for $15 \mathrm{~min}$ and permeabilized in $0.3 \%$ Triton X-100 for $5 \mathrm{~min}$ at room temperature. The cells were blocked for 30 min with $0.1 \%$ horse serum and probed with anti-cytochrome $c \mathrm{mAb}$ ( $1: 20$ dilution in $2 \% \mathrm{BSA})$ for $2 \mathrm{~h}$, and stained with FITC-conjugated anti-mouse IgG antibody (Amersham, UK). Nuclei were counterstained with $1 \mu \mathrm{g} \mathrm{ml}^{-1}$ of 4,6-diamidino-2-phenylindole (DAPI). Confocal laser scanning immunofluorescence microscopy was carried out on a Meridian microscope with excitation at 488,414 and $364 \mathrm{~nm}$ with an Argon laser.

\section{Acknowledgements}

Authors are thankful to Ms Nandini Rangaraj for assisting in confocal microscopy. Mr. PS Manogaran and Mr K Kennady helped us in flow cytometry. We are also thankful to Mr. Mubarak Ali and Mr. BVV Pardhasaradhi for help in cell culture. Ms. Hemalatha typed the manuscript. Financial support was provided by the Department of Biotechnology, Govt. of India.

\section{References}

1. Thompson CB (1995) Apoptosis in the pathogenesis and treatment of disease. Science 267: 1456-1462

2. Nicholson DW and Thornberry NA (1997) Caspases: killer proteases. Trends Biochem. Sci. 22: 299-306

3. Wolf BB and Green DR (1999) Suicidal tendencies: apoptotic cell death by caspase family proteinases. J. Biol. Chem. 274: 20049-20052

4. Salvesen GS and Dixit VM (1997) Caspases: intracellular signalling by proteolysis. Cell 91: $443-446$

5. Desagher S and Martinou JC (2000) Mitochondria as the central control point of apoptosis. Trends Cell Biol. 10: 369-377

6. Kroemer G, Zamzami N and Susin SA (1997) Mitochondrial control of apoptosis. Immunol. Today 18: 44-51
7. Bossy-WetzelE, NewmeyerDD and Green DR (1998) Mitochondrial cytochrome $C$ release in apoptosis occurs upstream of DEVD-specific caspase activation and independently of mitochondrial transmembrane depolarization. EMBO J. 17: $37-49$

8. Rosse T, Olivier R, Monney L, Rager M, Conus S, Fellay I, Jansen B and Borner C (1998) Bcl-2 prolongs cell survival after Bax-induced release of cytochrome C. Nature 391: $496-499$

9. Newmeyer DD, Farshon DM and Reed JC (1994) Cell-free apoptosis in Xenopus egg extracts: inhibition by $\mathrm{Bcl}-2$ and requirement for an organelle fraction enriched in mitochondria. Cell 79: 353-364

10. Liu X, Kim CN, Yang J, Jemmerson R and Wang X (1996) Induction of apoptotic program in cell-free extracts: requirement for dATP and cytochrome C. Cell 86: $147-157$

11. Yang J, Liu X, Bhalla K, Kim CN, Ibrado AM, Cai J, Peng TI, Jones DP and Wang X (1997) Prevention of apoptosis by Bcl-2: release of cytochrome C from mitochondria blocked. Science 275: 1129-1132

12. Kluck RM, Bossy-Wetzel E, Green DR and Newmeyer DD (1997) The release of cytochrome $\mathrm{C}$ from mitochondria: a primary site for $\mathrm{Bcl}-2$ regulation of apoptosis. Science 275: $1132-1136$

13. Susin SA, Zamzami N, Castedo M, Hirsch T, Marchetti P, Macho A, Daugas E, Geuskens M and Kroemer G (1996) Bcl-2 inhibits the mitochondrial release of an apoptogenic protease. J. Exp. Med. 184: 1331-1341

14. LiP, Nijhawan D, Budihardjo I, Srinivasula SM, Ahmed M, Alnemri ES and Wang $X$ (1997) Cytochrome $C$ and dATP-dependent formation of Apaf-1/caspase- 9 complex initiates an apoptotic protease cascade. Cell 91: 479-489

15. Antonsson B, Conti F, Ciavatta A, Montessuit S, Lewis S, Martinou I, Bernasconi L, Bernard A, Mermod JJ, Mazzei G, Maundrell K, Gambale F, Sadone R and Martinou JC. (1997) Inhibition of Bax channel-forming activity by Bcl-2. Science 277: $370-372$

16. Shimizu S, Narita M and Tsujimoto $Y$ (1999) Bcl-2 family proteins regulate the release of apoptogenic cytochrome $C$ by the mitochondrial channel VDAC. Nature 399: 483-487

17. Zoratti Mand Szabo I(1995) The mitochondrial permeability transition. Biochem Biophys. Acta. 1241: 139-176

18. Khar A (1986) Development and characterization of a rat histiocyte-macrophage tumor line. J. Natl. Cancer Inst. 76: 871-877

19. Martin SJ, Reutelingsperger CP, McGahon AJ, Rader J, van Schie RC, Laface DM and Green DR (1995) Early redistribution of plasma membrane phosphatidylserine is a general feature of apoptosis regardless of the initiating stimulus: inhibition by overexpression of Bcl-2 and Abl. J. Exp. Med. 182: 15451557

20. Lazebnik YA, Kaufman SH, Desnoyers S, Poirier GG and Earnshaw WC (1994) Cleavage of poly(ADP-ribose) polymerase by a proteinase with properties like ICE. Nature 371: $346-347$

21. Vayssiere JL, Petit PX, Risler Y and Mignotte B (1994) Commitment to apoptosis is associated with changes in mitochondrial biogenesis and activity in cell lines conditionally immortalized with simian virus 40 . Proc. Natl. Acad. Sci. USA 91: $11752-11756$

22. Zamzami N, Marchetti P, Castedo M, Hirsch T, Susin SA, Masse B and Kroemer G (1996) Inhibitors of permeability transition interfere with the disruption of mitochondrial membrane potential during apoptosis. FEBS Lett. 384, 153-157

23. Hickman JA (1992) Apoptosis induced by anticancer drugs. Cancer Metastasis Rev. 11: 121-139

24. Griffith TS, Brunner T, Fletcher SM, Green DR, Ferguson TA (1995) Fas ligandinduced apoptosis as a mechanism of immune privilege. Science 270: 1189 1192

25. Kausalya S, Hegde SP, Bright JJ and Khar A (1994) Mechanism of antibody dependent natural killer cell-mediated AK-5tumor cell death. Exp. Cell. Res. 212: 285-290

26. Khar A, Pardhasaradhi BVV, Varalakshmi CH, Ali AM and Kumari AL (1997) Natural killer cell as the effector which mediates in vivo apoptosis in AK-5 tumor cells. Cell. Immunol. 177: 86-92

27. Wyllie AH (1986) Glucocorticoid-induced thymocyte apoptosis is associated with endogenous endonuclease activation. Nature 284: 555-556

28. Verhoven B, Krahling S, Schlegel RA and Williamson P (1999) Regulation of phosphatidylserine exposure and phagocytosis of apoptotic T lymphocytes. Cell Death Differ. 6: 262-272

29. Tang DG, Li L, Zhu Z and Joshi B (1998) Apoptotis in the absence of cytochrome Caccumulation in the cytosol. Biochem. Biophys. Res. Commun. 242: 380-384 
30. Chauhan D, Pandey P, Ogata A, Teoh G, Krett N, Halgreen R, Rosen S, Kufe D, Kharbanda Sand Anderson K (1997) Cytochrome C dependent and independent induction of apoptosis in multiple myeloma cells. J. Biol. Chem. 272: 2999529997

31. Vander Heiden MG, Chandel NS, Williamson EK, Schumacker PT and Thompson CB (1997) Bcl- $X_{L}$ regulates the membrane potential and volume homeostasis of mitochondria. Cell 91:627-637

32. Jurgensmeier JM, Xie Z, Deveraux Q, Ellerby L, Bredesen D and Reed JC (1998) Bax directly induces release of cytochrome $C$ from isolated mitochondria. Proc. Natl. Acad. Sci. USA 95: 4997-5002

33. Martinou I, Desagher S, Antonsson B, Andre E, Fakan S and Martinou JC (1999) The release of cytochrome $C$ from mitochondria during apoptosis of NGFdeprived sympathetic neurons is a reversible event. J. Cell Biol. 144: 883-889

34. Marchetti P, Santos SA, Decaudin D, Gamen S, Castedo M, Hirsch T, Zamzam N, Naval J, Senik A and Kroemer G (1996) Apoptosis-associated derangement of mitochondrial function in cells lacking mitochondrial DNA. Cancer Res. 56 2033-2038

35. Crompton $\mathrm{M}$ (1999) The mitochondrial permeability transition pore and its role in cell death. Biochem. J. 341: 233-249

36. Loeffler M and Kroemer G (2000) The mitochondrion in cell death control: certainties and incognita. Exp. Cell Res. 256: 19-26
37. Kaufmann NK and Kaufman DG (1993) Cell cycle control, DNA repair and initiation of carcinogenesis. FASEB J. 12: 1189-1191

38. Khar A and Ali AM (1990) Adaptation of rat histiocytoma cells AK-5, to growth in culture. In vitro. Cell. Dev. Biol. 26: 1024-1025

39. Vermes I, Hannen C, Steffen-Nakken H and Reutelingsperger C (1995) A novel assay for apoptosis flow cytometric detection of phosphatidylserine expression on early apoptotic cells using fluorescein labelled annexin V. J. Immunol. Methods 184: $39-51$

40. Dimmeler S, Haendeler J, Nehls M and Zeiher AM (1997) Suppression of apoptosis by nitric oxide via inhibition of interleukin-1beta-converting enzyme (ICE)-like and cysteine protease protein (CPP)-32-like proteases. J. Exp. Med. 185: $601-607$

41. Gurtu V, Kain SR and Zhang G (1997) Fluorometric and colorimetric detection of caspase activity associated with apoptosis. Anal. Biochem. 251: 98-102

42. Stopper H, Jones $H$ and Zimmermann U (1987) Large scale transfection of mouse L-cells by electropermeabilization. Biochim. Biophys. Acta 900: 38-44

43. Poot M, Zhang YZ, Kramer JA, Wells KS, Jones LJ, Hanzel DK, Lugade AG, Singer VL and Haugland RP (1996) Analysis of mitochondrial morphology and function with novel fixable fluorescent stains. J. Histochem. Cytochem. 44: $1363-1372$ 